\title{
Study on in vitro propagation of Giao co lam (Gynostemma pentaphyllium Thunb.)
}

\author{
Trinh L. D. Ho*, Vi T. T. Nguyen, \& Kim T. A. Phan
}

Anh Dao Science Technology Agriculture Joint Stock Company, Ho Chi Minh City, Vietnam

\begin{abstract}
ARTICLE INFO
Research Paper

Received: March 17, 2018

Revised: April 27, 2018

Accepted: May 15, 2018

Keywords

Gynostemma pentaphyllium Thunb. MS medium

Multishoots

Propagation

\section{* Corresponding author}

Ho Le Diem Trinh

Email: hoahuongduong03@gmail.com

\section{ABSTRACT}

Giao co lam (Gynostemma pentaphyllium Thunb.) is a traditional medicine plant and endangered species in Vietnam. The research was carried out to establish the plant propagation for the purpose of conserving and exploting this endangered medicinal herbs. The young leaf and nodes of Giao co lam in vitro were used as explants in the study to evaluate the factors influencing the multiplication. Young leaf explants were excised and cultured in MS medium with TDZ from 0.1 to $1 \mathrm{mg} / \mathrm{L}$. After 10 weeks of culture, new shoots came out from their explants and the MS medium containing TDZ $0,7 \mathrm{mg} / \mathrm{L}$ gave the highest shoots (12.89 shoots/explant) with the average percentage of $74.67 \%$. When nodal explants were cultured on MS supplemented with BA at a concentration of 0.3 to $1.5 \mathrm{mg} / \mathrm{L}$ and IBA $0.5 \mathrm{mg} / \mathrm{L}$. After 6 weeks of culture, explants on MS medium supplemented with BA $1 \mathrm{mg} / \mathrm{L}$ and IBA $0,5 \mathrm{mg} / \mathrm{L}$ gave the highest shoots (7.39 shoots/explant) and their average percentage was $83.33 \%$. In comparison to the nodal explant medium in combination with BA $(0.5$ to $3 \mathrm{mg} / \mathrm{L})$ and NAA $0.2 \mathrm{mg} / \mathrm{L}$ for 4 weeks of culture, the best rapid shoot multiplication score was 3.67 times with $\mathrm{MS}+\mathrm{BA} 1.5 \mathrm{mg} / \mathrm{L}+\mathrm{NAA}$ $0.2 \mathrm{mg} / \mathrm{L}$ as compared to $\mathrm{MS}+\mathrm{BA} 1.0 \mathrm{mg} / \mathrm{L}+\mathrm{IBA} 0.5 \mathrm{mg} / \mathrm{L}$. Suitable medium for rooting was MS $+0.5 \mathrm{mg} / \mathrm{L}$ IBA with root shoots at $97.33 \%$, average roots at 5.29 roots/shoot after 4 weeks. On organic substrat, $70 \%$ coconut fiber and $30 \%$ composted cow manure gave the highest survival rate of $91.33 \%$. The plants grew and developed well during the nursery stage.
\end{abstract}

Cited as: Ho, T. L. D, Nguyen, V. T. T, \& Phan, K. T. A. (2018). Study on in vitro propagation of Giao co lam (Gynostemma pentaphyllium Thunb.). The Journal of Agriculture and Development 17(5), 84-92. 


\title{
Nghiên cứu quy trình nhân giống in vitro cây Giảo cổ lam (Gynostemma pentaphyllium Thunb.)
}

\author{
Hồ Lê Diễm Trinh*, Nguyễn Thị Tường Vi \& Phan Thị Á Kim \\ Công Ty Cổ Phần Khoa Học Công Nghệ Nông Nghiệp Anh Đào, TP. Hồ Chí Minh
}

\section{THÔNG TIN BÀI BÁO}

Bài báo khoa học

Ngày nhận: 17/03/2018

Ngày chỉnh sửa: $27 / 04 / 2018$

Ngày chấp nhận: 15/05/2018

\section{Từ khóa}

Cụm chồi

Giảo cổ lam

Môi trường MS

Nhân chồi

\section{*Tác giả liên hệ}

Hồ Lê Diễm Trinh

Email: hoahuongduong03@gmail.com

\section{TÓM TẮT}

Giảo cổ lam (Gynostemma pentaphyllium Thunb.) là một loại dược liệu quý trong $\mathrm{y}$ học cổ truyền Việt Nam. Nghiên cứu được tiến hành nhằm xây dựng quy trình nhân giống cây Giảo cổ lam với mục đích bảo tồn và phát triển loài dược liệu quý này. Mẫu lá non và đốt thân cây giảo cổ lam in vitro được làm nguyên liệu cho các thí nghiệm khảo sát ảnh hưởng đến sự nhân giống. Mẫu lá non được cắt và nuôi cấy trên môi trường MS (môi trường Murashige và Skoog) với TDZ (thidiazuron) từ 0,1 tới $1 \mathrm{mg} / \mathrm{L}$. Cụm chồi Giảo cổ lam được tạo thành cao nhất trên môi trường $\mathrm{MS}+\mathrm{TDZ} 0,7$ mg/L, với 74,67\% mẫu cảm ứng với 12,89 chồi/mẫu sau 10 tuần nuôi cấy. Mẫu đốt thân được nuôi cấy trên môi trường MS với $\mathrm{BA}$ (6-benzyl adenine) từ 0,3 tới $1,5 \mathrm{mg} / \mathrm{L}$ và $\mathrm{IBA}$ (indole-3-butyric acid) $0,5 \mathrm{mg} / \mathrm{L}$ ). Sau 6 tuần nuôi cấy trên môi trường MS + BA $1 \mathrm{mg} / \mathrm{L}$ + IBA $0,5 \mathrm{mg} / \mathrm{L}, 83,33 \%$ mẫu đoạn thân cảm ứng tạo cụm chồi với 7,39 chồi/mẫu. So sánh môi trường đốt thân với sự kết hợp BA (0,3-5 mg/L) và NAA (1-naphthaleneacetic acid) 0,2 mg/L sau 4 tuần nuôi cấy, hệ số nhân nhanh chồi tốt nhất đạt 3,67 lần trên môi trường $\mathrm{MS}+\mathrm{BA} 1,5 \mathrm{mg} / \mathrm{L}+\mathrm{NAA} 0,2 \mathrm{mg} / \mathrm{L}$ khi so với $\mathrm{MS}+\mathrm{BA} 1,0 \mathrm{mg} / \mathrm{L}+\mathrm{IBA} 0,5 \mathrm{mg} / \mathrm{L}$. Môi trường thích hợp để cảm ứng tạo rễ là $\mathrm{MS}+0,5 \mathrm{mg} / \mathrm{L} \mathrm{IBA}$ với tỷ lệ chồi tạo rễ đạt $97,33 \%$, số rễ trung bình đạt 5,29 rễ/chồi sau 4 tuần. Trên giá thể hữu cơ phối trộn $70 \%$ xơ dừa và $30 \%$ phân bò ủ hoai cho tỷ lệ cây sống cao đạt tới $91,33 \%$, cây sinh trưởng và phát triển tốt trong giai đoạn vườn ươm.

\section{1. Đặt Vấn Đề}

Cùng với sự phát triển ngày càng cao của xã hội, xu hướng sử dụng dược liệu có nguồn gốc tự nhiên đang ngày càng được ưu tiên. Nhiều dược liệu có nguồn gốc từ thực vật đã và đang được sử dụng rộng rãi như là nguồn cung cấp các loại thuốc chữa bệnh hoặc thực phẩm chức năng cho đại đa số người dân trên thế giới (Pradhan \& ctv., 2015). Giảo cổ lam (Gynostemma pentaphyllium Thunb.) là loài dược liệu có giá trị phù hợp với nhiều tiểu vùng khí hậu trong nước và đặc biệt ở Quảng Nam... Trong thân lá Giảo cổ lam chứa hơn 100 loại saponin, nhiều flavonoid và các thành phần hóa học khác như amino acid, vitamin và các nguyên tố vi lượng như $\mathrm{Zn}, \mathrm{Fe}, \mathrm{Se}, \ldots$ Giảo cổ lam nổi tiếng với khả năng kháng oxy hóa, giúp cơ thể tăng khả năng chống lại stress, làm lành vết thương, tăng cường sức khỏe, làm tan huyết khối, giúp ổn định huyết áp, phòng chống các tai biến về tim, mạch, não,... (Mishra \& Joshi, 2011; Vo, 2012). Theo kết quả điều tra mới đây cho thấy, tại vùng núi Quảng Nam, Giảo cổ lam mọc tự nhiên với diện tích khoảng 20 ha, phổ biến ở khu vực rừng nguyên sinh của xã Trà Linh, Trà Cang và Trà Nam (huyện Nam Trà $\mathrm{My}$ ), nơi có độ che phủ từ $50 \%$ trở lên, hầu hết ở độ cao từ $1000 \mathrm{~m}$ trở lên so với mặt nước biển. Hiện nay, Giảo cổ lam chủ yếu được nhân giống bằng hạt hoặc giâm cành, vì vậy hệ số nhân giống không cao, chất lượng cây giống không đồng đều. Để có lượng cây giống lớn, đồng nhất về hình thái và ổn định về mặt di truyền phục vụ cho sản xuất cần áp dụng công nghệ sinh học, đặc biệt là nhân 
giống in vitro. Nghiên cứu này được thực hiện nhằm thiết lập quy trình nhân giống in vitro cây Giảo cổ lam 5 lá, bắt đầu từ khâu vào mẫu, nhân giống và huấn luyện cây ngoài vườn ươm để thu được những cây giống in vitro có chất lượng tốt nhất.

\section{Vật Liệu và Phương Pháp Nghiên Cứu}

\subsection{Vật liệu nghiên cứu}

Cây Giảo cổ lam 5 lá sinh trưởng tốt được thu thập tại vùng núi xã Trà Nam, huyện Nam Trà My, tỉnh Quảng Nam từ độ cao $1.000 \mathrm{~m}$ trở lên so với mặt nước biển.

\subsection{Phương pháp khử trùng}

Đoạn thân $(1,0$ - 1,5 cm) bánh tẻ mang chồi ngủ được rửa sạch bằng xà phòng $5 \%$, sau đó rửa lại dưới vòi nước chảy 10 phút. Khử trùng sơ bộ bằng cồn $70 \%$ trong 30 giây, rửa lại bằng nước cất vô trùng 3 lần. Mẫu tiếp tục được lắc với javel nồng độ $20 \%$ trong 10 phút, sau đó rửa lại bằng nước cất vô trùng $3-5$ lần. Cắt mẫu sau khi khử trùng thành từng đoạn mang chồi ngủ và cấy trên môi trường MS (Murashige \& Skoog, 1962) bổ sung saccharose $30 \mathrm{~g} / \mathrm{L}$ và agar $8 \mathrm{~g} / \mathrm{L}$ để tạo chồi in vitro làm nguyên liệu cho các thí nghiệm tiếp theo.

\subsection{Tái sinh chồi từ mẫu lá và đoạn thân}

Mẫu lá non in vitro 4 tuần tuổi được cắt và đặt lên môi trường MS có bổ sung TDZ với các nồng độ khác nhau $(0,1-1,0 \mathrm{mg} / \mathrm{L})$. Đoạn thân có chứa 1 mắt từ chồi Giảo cổ lam in vitro được cắt và đặt lên môi trường $\mathrm{MS}$ có bổ sung $\mathrm{BA}$ với các nồng độ khác nhau (0,3-1,5 mg/L) kết hợp với IBA $0,5 \mathrm{mg} / \mathrm{L}$ để thăm dò khả năng tái sinh chồi.

\subsection{Nhân nhanh chồi}

Cụm chồi tái sinh từ lá và đoạn thân có chiều cao từ $0,3-0,5 \mathrm{~cm}$, chồi sinh trưởng phát triển bình thường được chuyển sang môi trường nhân nhanh là MS có bổ sung $\mathrm{BA}(0,5-3 \mathrm{mg} / \mathrm{L})$ kết hợp với NAA $0,2 \mathrm{mg} / \mathrm{L}$ để thăm dò khả năng nhân chồi.

\subsection{Tạo rễ cây con in vitro}

Chồi in vitro sau giai đoạn nhân nhanh có chiều cao 4,5-5,0 cm, lá xanh, sinh trưởng phát triển bình thường sẽ được chuyển sang môi trường MS có bổ sung IBA (0-1,5 mg/L) để cảm ứng tạo rễ.

\subsection{Huấn luyện cây con ngoài vườn ươm}

Sau 30 ngày nuôi cấy trên môi trường cảm ứng tạo rễ, cây con hoàn chỉnh được chuyển ra các giá thể khác nhau. Một số nghiên cứu cho thấy, cây con in vitro thích nghi trên giá thể xơ dừa trong giai đoạn vườn ươm (Tran \& ctv., 2009) nên ở đây chỉ khảo sát giá thể với thành phần chính là xơ dừa và có bổ sung thêm 1 số thành phần hữu cơ khác. Cụ thể: $1 /$ xơ dừa: cát $(7: 3), 2$ / xơ dừa: đất (7: 3$), 3 /$ xơ dừa: trấu $(7: 3), 4 /$ xơ dừa: phân bò hoai $(7: 3)$ để khảo sát khả năng thích nghi của cây trong điều kiện vườn ươm. Cây được đặt trong nhà lưới, che phủ bằng nylon và lưới đen có khả năng cản ánh sáng 70\%. Tưới nước giữ ẩm 2 lần/ngày.

\subsection{Phương pháp bố trí thí nghiệm và xử lý số liệu}

Các thí nghiệm được bố trí mỗi công thức lập lại 3 lần, mỗi lần 50 mẫu. Các chỉ tiêu theo dõi được quan sát và đo đếm sau 10 và 6 tuần tương ứng với thí nghiệm tạo cụm chồi từ lá và đoạn thân, 4 tuần với các thí nghiệm nhân nhanh và ra rễ. Số liệu được phân tích thống kê bằng phần mềm Statgraphics centurion 16.1 cho Windows. Các số trung bình trong cột với các ký tự khác biệt có ý nghĩa ở mức $P<0,05$.

\section{8. Điều kiện nuôi cấy}

Thí nghiệm được thực hiện tại Phòng thí nghiệm của Công ty Cổ phần Khoa học Công nghệ Nông nghiệp Anh Đào. Thời gian chiếu sáng $16 \mathrm{~h} /$ ngày, nhiệt độ $25 \pm 2^{0} \mathrm{C}$, cường độ chiếu sáng là 2000 - 2500 Lux. Môi trường nuôi cấy được điều chỉnh $\mathrm{pH} 5,8$ trước khi hấp khử trùng ở $121^{\circ} \mathrm{C}, 1,1 \mathrm{~atm}$ trong 20 phút. 


\section{Kết Quả và Thảo Luận}

\section{1. Ảnh hưởng của $T D Z$ đến khả năng phát sinh chồi từ mẫu lá}

Sau 10 tuần nuôi cấy, trên môi trường MS bổ sung TDZ ở các nồng độ khác nhau (0,1-1mg/L), kết quả cho thấy TDZ ảnh hưởng rõ rệt đến khả năng phát sinh hình thái và tái sinh chồi từ mẫu lá non Giảo cổ lam (Bảng 1$)$. Ở nồng độ thấp, mẫu cảm ứng tạo rễ $(0,1 \mathrm{mg} / \mathrm{L})$ và sẹo $(0,3$ $\mathrm{mg} / \mathrm{L})$. Với nồng độ $0,7 \mathrm{mg} / \mathrm{L} \mathrm{TDZ}$, số mẫu cảm ứng tạo chồi đạt $74,67 \%$ và số lượng chồi trên mẫu đạt được tương đối cao với 12,89 chồi/mẫu, chồi có màu xanh đậm. Khi tăng nồng độ TDZ lên đến $1,0 \mathrm{mg} / \mathrm{L}$, số chồi/mẫu giảm xuống đáng kể, đồng thời mẫu có hiện tượng chuyển sang màu nâu. Trên môi trường không bổ sung TDZ, mẫu bị vàng, hóa nâu và chết lụi. Kết quả này phù hợp với nhận định của Duong (2011) khi cho rằng TDZ là chất có hoạt tính cytokinin và cũng có hoạt tính auxin nên khi bổ sung vào môi trường nuôi cấy ở nồng độ cao, thường ức chế sự tái sinh dẫn đến hiện tượng mẫu chuyển sang màu nâu đen hoặc chết. Bên cạnh đó, sự có mặt của TDZ trong môi trường, ở nồng độ thấp hoặc vừa phải, đã thúc đẩy khả năng sinh tổng hợp cytokinin nội sinh ở mô thực vật (Nguyễn Thị Liễu \& ctv., 2010). Nghiên cứu của Lyyra (2006) đã kết luận môi trường MS bổ sung TDZ $0,1 \mathrm{mg} / \mathrm{L}$ cho hiệu quả tái sinh chồi cây Liễu trắng (Salix nigra) cao. Trong khi với đối tượng Thu hải đường (Begonia tuberous) tỷ lệ tái sinh chồi đạt 83,33\% trên môi trường MS $1 / 2$ có bổ sung TDZ $0,2 \mathrm{mg} / \mathrm{L}$ (Duong \& ctv., 2009). Trong phạm vi nghiên cứu này, nồng độ TDZ $0,7 \mathrm{mg} / \mathrm{L}$ cho hiệu quả tái sinh cụm chồi tốt nhất từ mẫu lá non Giảo cổ lam.

\section{2. Ảnh hưởng của $B A$ và IBA tới khả năng tái sinh chồi từ đoạn thân}

Sau 6 tuần nuôi cấy, kết quả cho thấy ở tất cả các công thức thí nghiệm, tỷ lệ mẫu tạo chồi tương đối cao từ $73,33-86,67 \%$ (Bảng 2). Tuy nhiên, số chồi/mẫu có sự khác nhau rõ rệt giữa các nghiệm thức. Trong đó, ở nồng độ BA $1 \mathrm{mg} / \mathrm{L}$ kết hợp với IBA $0,5 \mathrm{mg} / \mathrm{L}$, cho tỷ lệ mẫu tạo chồi cao nhất $(83,33 \%)$ và số lượng chồi trên mẫu đạt lớn nhất $(7,39)$. Kết quả này phù hợp với nhận định của Bui (2000) khi cho rằng sự phát sinh và phát triển của chồi chịu tác động cân bằng của chất điều hòa sinh trưởng auxin và cytokinin. Sự kết hợp của hai nhóm chất điều hòa sinh trưởng trên tạo nên một thế cân bằng mới phá vỡ trạng thái ngủ của chồi. Đồng thời cytokinin phối hợp với auxin nồng độ thấp giúp cho sự tăng trưởng chồi non và khởi phát sự tạo mới mô phân sinh ngọn chồi từ nhu mô. Nghiên cứu của Jalaa \& Patchpoonporna (2012) cũng cho kết quả tương tự với số chồi/mẫu cao nhất là 6,8 chồi khi sử dụng chồi ngọn và chồi bên Giảo cổ lam nuôi cấy trên môi trường $\mathrm{MS}$ kết hợp với $\mathrm{BA} 1 \mathrm{mg} / \mathrm{L}$ và NAA $0,1 \mathrm{mg} / \mathrm{L}$.

\section{3. Ảnh hưởng của $\mathrm{BA}$ và NAA tới khả năng nhân nhanh chồi}

Trong quá trình nhân giống in vitro, sự phối hợp giữa auxin và cytokinin với nồng độ và tỷ lệ thích hợp có tác động đáng kể tới sự hình thành chồi và chất lượng chồi. Bổ sung $\mathrm{BA}$ với nồng độ từ $0,5-3,0 \mathrm{mg} / \mathrm{L}$ kết hợp với $\mathrm{NAA} 0,2 \mathrm{mg} / \mathrm{L}$ vào môi trường nuôi cấy đã cải thiện hệ số nhân chồi Giảo cổ lam từ 2,12-3,93 lần sau 4 tuần nuôi cấy, cao hơn công thức đối chứng (1,17 lần). Hệ số nhân chồi tăng dần khi tăng nồng độ $\mathrm{BA}$ từ 0,5 $2,0 \mathrm{mg} / \mathrm{L}$. Tuy nhiên, khi tăng nồng độ $\mathrm{BA}$ lên 3,0 mg/L, tác nhân này đã ức chế khả năng nhân chồi, do đó các chỉ tiêu hệ số nhân chồi, chiều cao chồi và chất lượng chồi đều giảm. Hệ số nhân chồi đạt được cao nhất là 3,93 lần khi bổ sung $2 \mathrm{mg} / \mathrm{L}$ $\mathrm{BA}$ vào môi trường nuôi cấy, tuy nhiên về hình thái thì chiều cao và chất lượng chồi kém hơn so với các chồi nuôi trên môi trường chứa $1,5 \mathrm{mg} / \mathrm{L}$ BA (Bảng 3).

Như vậy, $1,5 \mathrm{mg} / \mathrm{L}$ được lựa chọn là nồng độ BA tốt nhất để nhân chồi Giảo cổ lam. Bui \& ctv. (2015) đã sử dụng môi trường MS bổ sung Kinetin $0,4 \mathrm{mg} / \mathrm{L}$ và $\mathrm{BA} 0,5 \mathrm{mg} / \mathrm{L}$ đã thu được hệ số nhân chồi đạt 4,36 lần sau 30 ngày nuôi cấy với vật liệu là chồi đơn in vitro tái sinh từ mẫu cấy ban đầu. Trong khi kết quả nghiên cứu này cho thấy từ một mẫu cấy ban đầu có thể tạo ra khoảng 24-35 chồi sau 42 ngày nuôi cấy cảm ứng tạo cụm chồi và 30 ngày nhân nhanh.

\section{4. Ảnh hưởng của IBA lên khả năng tạo rễ cây con in vitro}

Để tạo rễ cho cây in vitro cần sử dụng auxin IBA bổ sung vào môi trường nuôi cấy. Sau 4 tuần nuôi cấy, ghi nhận trên môi trường có hoặc không bổ sung IBA, chồi đều có khả năng tạo rễ, điều này chứng tỏ lượng auxin nội sinh trong Giảo cổ lam in vitro ở mức cao. Tuy nhiên, bổ sung IBA vào môi trường nuôi cấy đã làm tăng số rễ/cây 

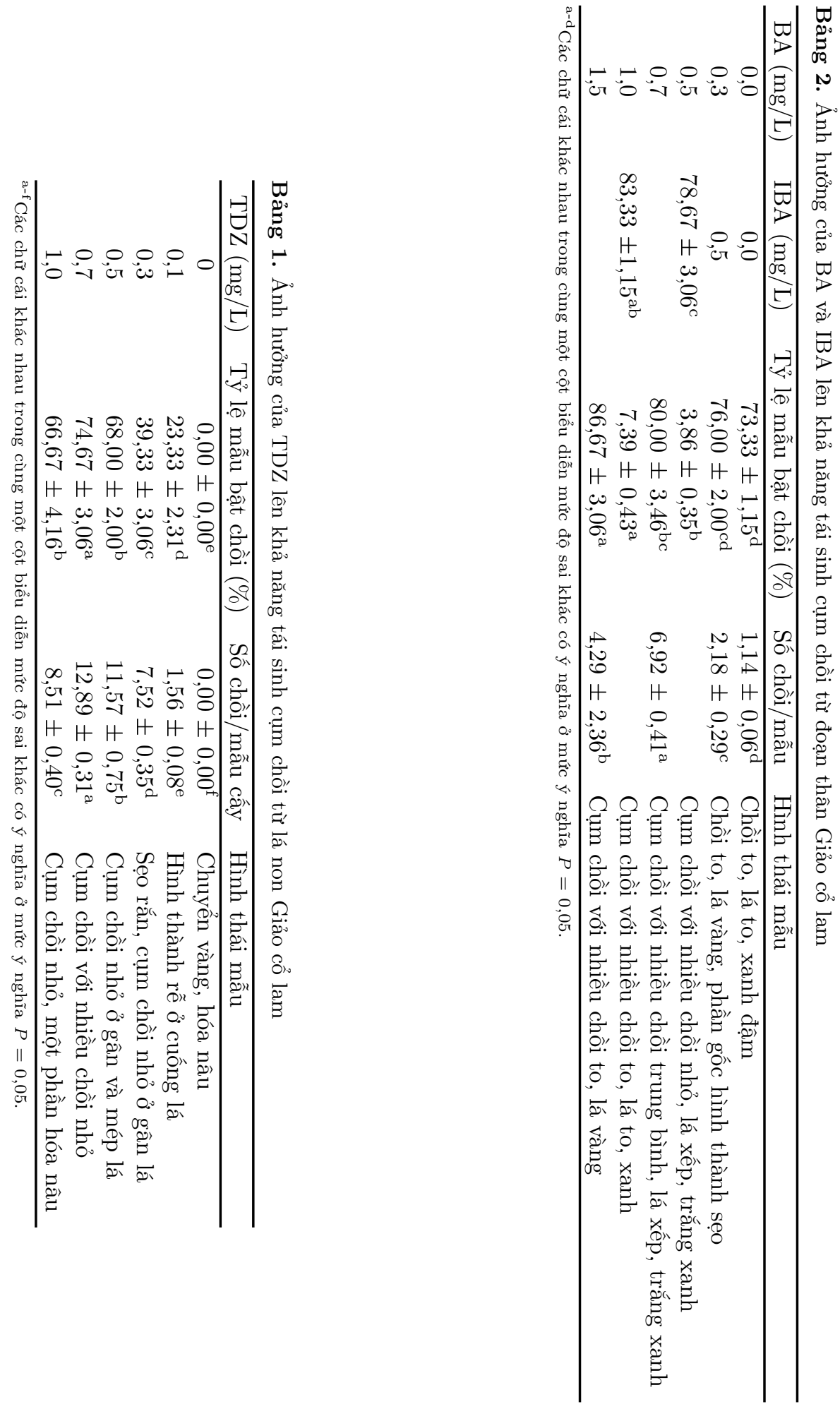

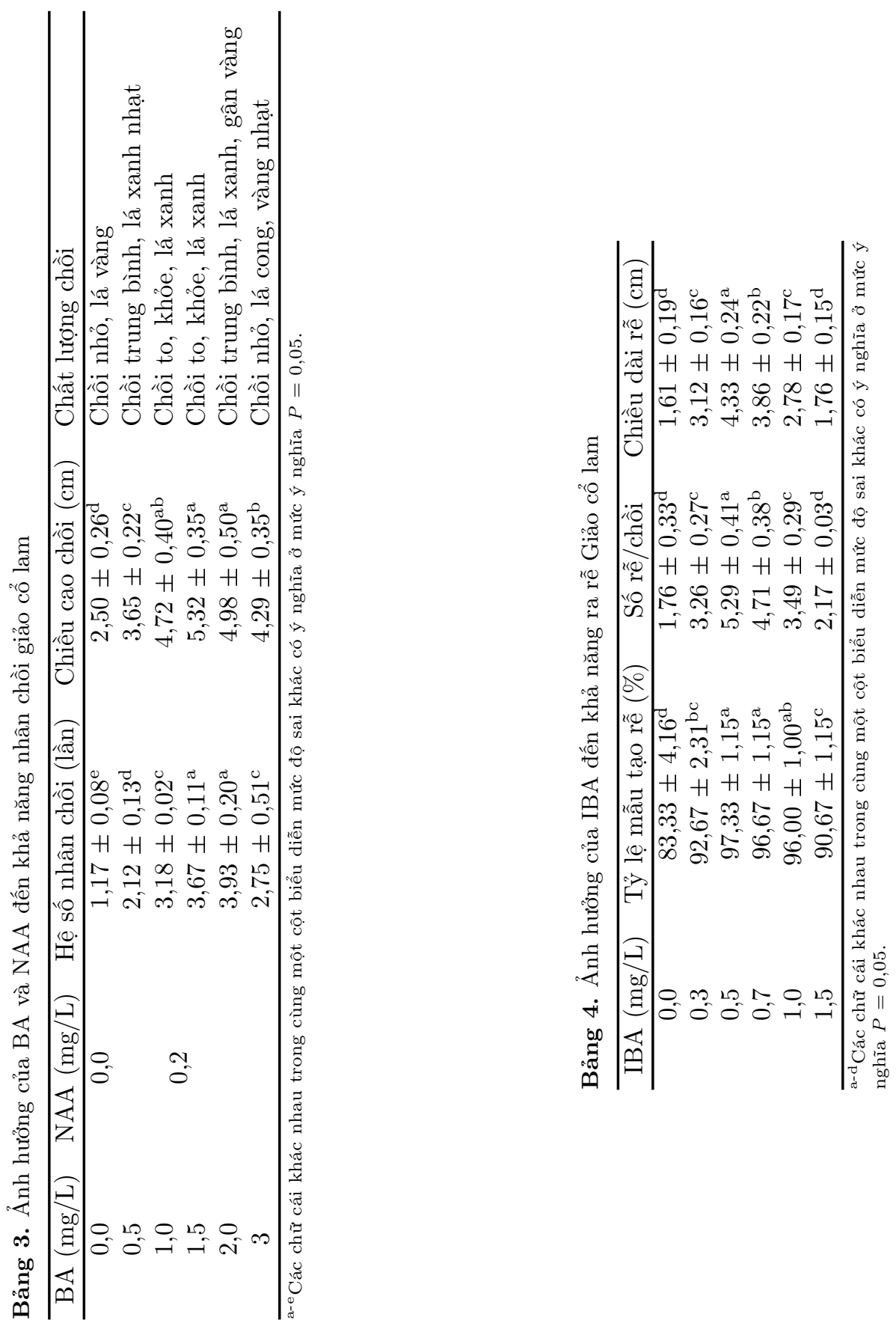
và chiều dài trung bình rễ, đặc biệt ở công thức bổ sung IBA $0,5 \mathrm{mg} / \mathrm{L}$ cho tỷ lệ mẫu tạo rễ đạt $97,33 \%$ và số rễ/chồi đạt cao nhất tới 5,29 , chiều dài rễ cũng đạt tới 4,33 cm (Bảng 4). Như vậy, môi trường nuôi cấy chồi Giảo cổ lam có bổ sung IBA $0,5 \mathrm{mg} / \mathrm{L}$ cho tỷ lệ ra rễ cao nhất, xuất hiện nhiều rễ phụ. Thực vậy, việc bổ sung các auxin như IBA vào môi trường nuôi cấy ở nhiều loài thực vật dẫn đến sự cảm ứng tạo rễ bất định (Ludwig-Muller, 2000). Cũng theo Bui (2000), auxin hình thành rễ bất định tác động vào hai giai đoạn là thành lập rễ sơ khởi và kéo dài. Ở giai đoạn đầu cần auxin ở nồng độ cao để tạo rễ sơ khởi và giai đoạn sau cần auxin nồng độ thấp để kéo dài rễ. Do đó, IBA ở nồng độ thấp $(\leq 1,0$ $\mathrm{mg} / \mathrm{L}$ ) thường được sử dụng trong môi trường tạo rễ in vitro trong giai đoạn tạo cây hoàn chỉnh.

\section{5. Ảnh hưởng của các loại giá thể lên tỷ lệ sống của cây con in vitro}

Sau khi cảm ứng tạo rễ để tạo cây hoàn chỉnh, chuyển cây con in vitro ra vườn ươm và theo dõi trong vòng 4 tuần. Kết quả (Bảng 5) cho thấy, khả năng thích nghi của cây con nuôi cấy mô khi đưa ra vườn ươm tương đối cao, tỷ lệ sống sót đạt từ 72-91,33\% tùy thuộc vào loại giá thể. Trong đó, giá thể xơ dừa: phân bò hoai (7:3) cho tỷ lệ cây sống cao nhất $91,33 \%$ và chiều cao cây đạt 9,5 cm. Về hình thái cây cứng cáp, bộ lá phát triển tốt, phiến lá to, màu xanh đậm, rễ khỏe và đang hình thành nhiều rễ mới. Giá thể xơ dừa nhẹ, thoát nước tốt giúp hệ rễ phát triển mạnh, kết hợp với phân chuồng hoai cung cấp dinh dưỡng cho cây, đây là giá thể thích hợp nhất trong số các loại giá thể đưa dùng để ườm cây trong vườn ươm (Hình 1).

\section{Kết Luận}

Nguồn vật liệu đưa vào nuôi cấy khác nhau cho tỷ lệ tái sinh chồi Giảo cổ lam khác nhau. Đối với mẫu lá: Môi trường MS kết hợp với TDZ ở nồng độ $0,7 \mathrm{mg} / \mathrm{L}$ thích hợp nhất cho tái sinh cụm chồi. Môi trường này cho tỷ lệ mẫu cảm ứng tạo cụm chồi đạt 74,67\% và 12,89 chồi/mẫu sau 10 tuần nuôi cấy. Đối với mẫu đoạn thân: môi trường MS kết hợp với $\mathrm{BA} 1 \mathrm{mg} / \mathrm{L}$ và $\mathrm{IBA} 0,5 \mathrm{mg} / \mathrm{L}$ cho tỷ lệ mẫu cảm ứng cụm chồi đạt 83,33\% và đạt 7,39 chồi/mẫu sau 6 tuần nuôi cấy.

Môi trường thích hợp cho nhân nhanh chồi in vitro là MS kết hợp với $\mathrm{BA} 1,5 \mathrm{mg} / \mathrm{L}$ và $\mathrm{NAA} 0,2$ 


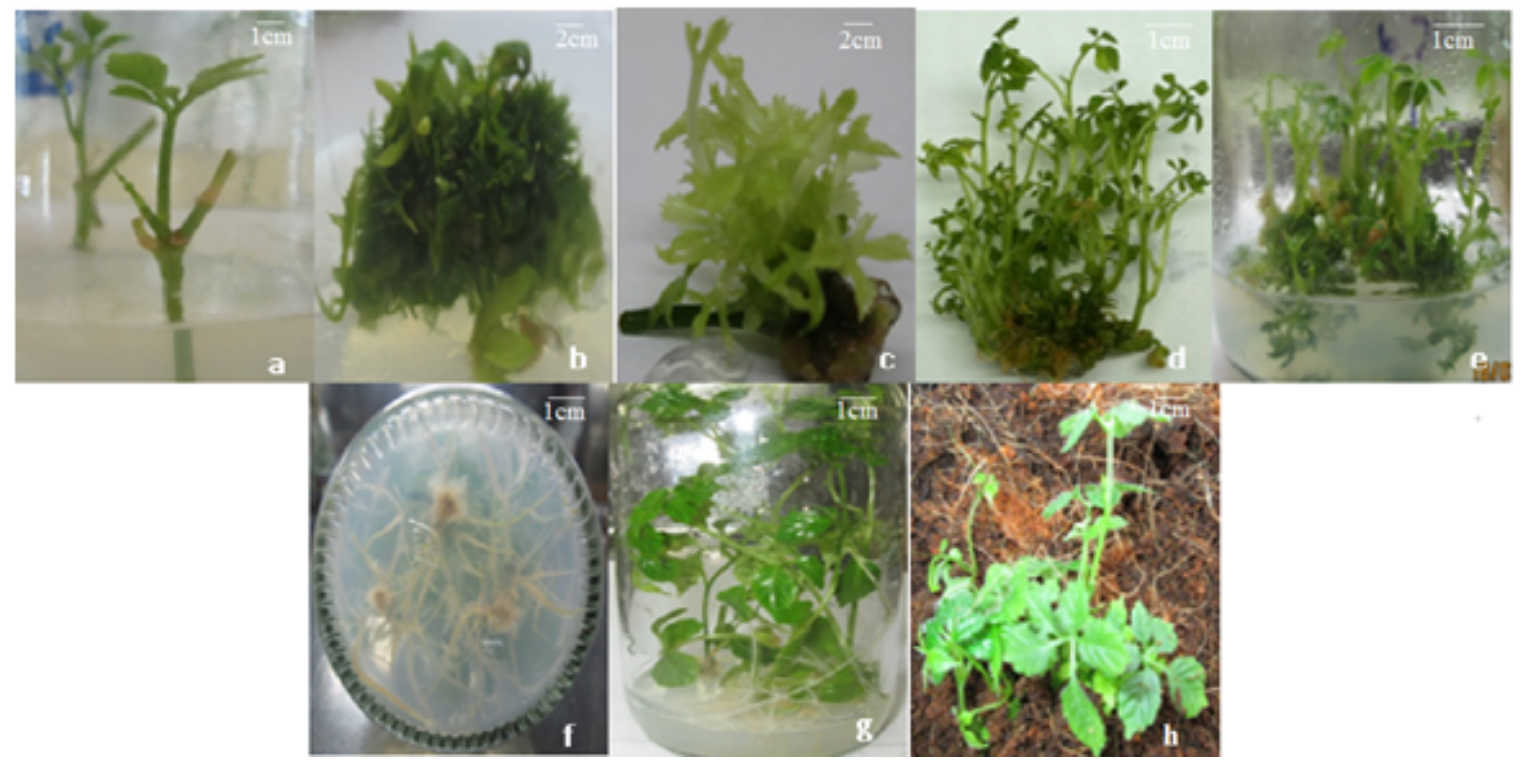

Hình 1. a) Chồi GCL tái sinh từ đoạn thân. b) Cụm chồi tái sinh từ lá trên môi trường MS $+\mathrm{TDZ} 0,7$ $\mathrm{mg} / \mathrm{L}$. c) cụm chồi tái sinh từ đoạn thân trên môi trường $\mathrm{MS}+\mathrm{BA} 1 \mathrm{mg} / \mathrm{L}+\mathrm{IBA} 0,5 \mathrm{mg} / \mathrm{L}$. d, e) nhân nhanh chồi Giảo cổ lam trên môi trường $\mathrm{MS}+\mathrm{BA} 1,5 \mathrm{mg} / \mathrm{L}+\mathrm{NAA} 0,2 \mathrm{mg} / \mathrm{L} . \mathrm{f}, \mathrm{g})$ tạo cây hoàn chỉnh trên môi trường $\mathrm{MS}+\mathrm{IBA} 0,5 \mathrm{mg} / \mathrm{L}$. h) thích nghi cây vườn ươm trên giá thể xơ dừa $(70 \%)$ : phân bò hoai $(30 \%)$.

mg/L. Trên môi trường này sau 4 tuần nuôi cấy hệ số nhân đạt 3,67 lần, chiều cao chồi đạt 5,32 $\mathrm{cm}$ cho hình thái chồi mập, cuống lá to và xanh đậm. Chồi in vitro cảm ứng tạo rễ tốt nhất trên môi trường MS kết hợp với IBA 0,5 mg/L. Ỏ môi trường này, sau 4 tuần nuôi cấy, tỷ lệ ra rễ đạt $97,33 \%$, số rễ/chồi là 5,29 và chiều dài rễ đạt 4,33 $\mathrm{cm}$. Giá thể xơ dừa: phân bò với tỷ lệ $7: 3$ cho tỷ lệ cây sống ngoài vườn ươm cao nhất, sau 4 tuần theo dõi, đạt 91,33\% với chiều cao cây trung bình $9,5 \mathrm{~cm}$.

\section{Tài Liệu Tham Khảo (References)}

Bui, L. D., Nguyen, T. T., Nguyen, D. V., Nguyen, B. V., La, H. V., \& Ngo, B. X. (2015). Study on the ability of propagation of Jiaogulan (Gynostemma pentaphyllum Thunb.) in vitro. Journal of Agriculture and Rural Development 11, 249-256.

Bui, V. T. (2000). Plant physiology. In: General plant physiology II. University of Science, Ho Chi Minh City, Vietnam.

Duong, N. T (2011). Plant biotechnology: basic and applied research. Ho Chi Minh City, Vietnam: HCMC Agricultural Publishing House.

Duong, N. T., Nguyen, H. T., \& Mai, P. X. (2009). A highly efficient protocol for Micropropagation of $\mathrm{Be}$ - gonia tuberous. Protocols for In Vitro Propagation of Ornamental Plants 589, 15-20.

Jalaa, A., \& Patchpoonporna, W. (2012). Effect of BA NAA and 2,4-D on Micropropagation of Jiaogulan (Gynostemma pentaphyllum Makino). International Transaction Journal of Engineering, Management, \& Applied Sciences \& Technologies 3(4), 363-370.

Ludwig-Muller, J. (2000). Indole-3-butyric acid in plant growth and development. Journal of Plant Growth Regulation 32(2-3), 219-230.

Lyyra, S. (2006). In vitro regeneration of Salix nigra from adventitious shoots. Tree Physiology 26(7), 969-975.

Mishra, R. N., \& Joshi, D. (2011). Jiaogulan (Gynostemma pentaphyllum): The Chinese RasayanCurrent Research Scenario. International Journal of Research in Pharmaceutical and Biomedical sciences 2(4), 14831502 .

Murashige, T., \& Skoog, F. (1962). A revised medium for rapid growth and bioassays with tobacco tissue cultures. Plant Physiology 15(3), 473-497.

Nguyen, L. T., Nguyen, T. T., \& Nguyen, K. V. (2010). The adventitious root induce of Ngoc Linh ginseng (Panax vietnamesis, Ha et Grushv.) in vitro cultures. VNU Journal of Science, Natural Sciences and Technology 27, 30-36.

Pradhan, N., Gavalli, J., \& Waghmare, N. (2015). WHO guidelines for standardization of herbal drugs. International Ajurvedic Medicinal Journal 3(8), 2238-2243. 
Tran, B. T., Bui, T. V., \& Tran, L. N. (2009). Effects of different substrates, varieties, nutrient solutions on growth and yield of hydroponic lettuce, winter-spring 2007-2008. Can Tho University Journal of Science $11,339-346$.
Vo, C. V. (2012). Vietnamese herbal medicine. Ha Noi, Vietnam: Medical Publishing House. 